\title{
ACUTE TOXICITY AND ANTINOCICEPTIVE ACTIVITY OF SAPONINS RICH FRACTION OF DIOSCOREA DELTOIDEA (WALL)
}

\author{
Niaz Ali ${ }^{1 凶}$, Nur-Ul-Ain', Muhammad Nabi', Zakia \\ Subhan ${ }^{1,2}$, Shakir Ullah ${ }^{1,3}$, Ulfat Sultana ${ }^{1,4}$, Bilal Shams ${ }^{5}$
}

\section{ABSTRACT}

OBJECTIVE: To evaluate the saponins rich fraction of Dioscorea deltoidea (D. deltoidea) for possible antinociceptive activity.

METHODS: Saponins were extracted from the crude methanolic extract of $D$. deltoidea (Wall). Presence of saponins was confirmed through phytochemical screenings. Acute toxicity test was performed to determine safe dose range of the saponins rich fraction (n-butanol fraction) using balb $\mathrm{C}$ Mice. The saponins rich fraction was assessed for possible antinociceptive activity using acetic acid induced writhing method and hot plate method. Data was analyzed using Graph Pad Prism 6. ANOVA was used to determine the significance of test samples versus positive control at $95 \% \mathrm{Cl}$ with $\mathrm{p}<0.05$.

RESULTS: The results showed that crude saponin rich fraction was safe up to test dose of $1000 \mathrm{mg} / \mathrm{kg}$ administered orally. In acetic acid induced writhing method, its test samples in doses of 10 and $50 \mathrm{mg} / \mathrm{kg}$ showed respectively $75.51 \%$ and $85.71 \%$ inhibition of writhing, while diclofenac sodium showed $74.4 \%$ inhibition of writhing. Percent inhibition of latency time of test samples increased from $87.87 \%$ to $133.6 \%$ in test doses of $10 \mathrm{mg} / \mathrm{kg}$ to $100 \mathrm{mg} / \mathrm{kg}$ dose, respectively, while Tramadol showed latency time of $85.12 \%$ within 30 minutes of its administration.

CONCLUSION: Saponins rich $\mathrm{n}$-butanol fraction of Dioscorea deltoidea (D.deltoidea) showed significant antinociceptive activity.

KEY WORDS: Diclofenac Sodium (MeSH); Analgesics (MeSH); Dioscorea deltoidea (Non-MeSH); Writhing (Non-MeSH); Tramadol (MeSH); N-butanol (MeSH); Ethyl-acetate (Non-MeSH); chloroform (MeSH); N-hexane (Non$\mathrm{MeSH})$; Acetic Acid (MeSH).

THIS ARTICLE MAY BE CITED AS: Ali N, Nur-ul-Ain, Nabi M, Subhan Z, Ullah S, Sultana U, Shams B. Acute toxicity and antinociceptive activity of saponins rich fraction of Dioscorea deltoidea (wall). Khyber Med Univ J 2020; I2(2): I07-I2. DOI: I0.35845/kmuj.2020.19787.

\section{INTRODUCTION}

$\mathrm{P}$ ain is an unpleasant emotional and sensory experience related to potential or actual tissue damage.' Medicinal plants are constantly used since creature of human beings for the management of various diseases including pain. Opiates and nonsteroidal anti inflammatory drugs (NSAIDs) are mostly used analgesic drugs, which may not be helpful in all cases, because of their adverse effects and poor pain management. Opiates cause tolerance, addiction and physical dependence. ${ }^{2}$ NSAIDs are associated with gastrointestinal disturbances like stomach and or duodenal ulceration. Morphine is associated with tolerance, hypotension and drug dependence. Thus, search for a safe and effective analgesic is the need of the time. Plants of medicinal importance are in use for therapeutic purposes since many years. Many of these plants had been used for management of pain with acceptable safety profile. ${ }^{2,4}$

Family Dioscoreaceae consists of 600 species that are distributed throughout
I. Department of Pharmacology, Institute of Basic Medical Sciences (IBMS), Khyber Medical University, Peshawar, Pakistan

2. Department of Pharmacology, Khyber Medical University Institute of Medical Sciences, Kohat, Pakistan

3. Department of Pharmacy, University of Malakand, Chakdara, Dir Lower, Pakistan

4. Department of Pharmacology, Rehman Medical College, Peshawar, Pakistan

5. Department of Pharmacy, University of Peshawar, Peshawar, Pakistan.

Email凶: niazpharmacist@yahoo.com Contact \# : +92-345-9537478

$\begin{array}{ll}\text { Date Submitted: } & \text { October 07, } 2019 \\ \text { Date Revised: } & \text { May 05, 2020 } \\ \text { Date Accepted: } & \text { May 07, 2020 }\end{array}$

the world. Mostly they are found in the tropical regions of the world. ${ }^{5}$ Dioscorea deltoidea belongs to family Dioscoreaceae that produces rhizomes or tubers, which have rich economical as well as medicinal significance. D. deltoidea is one of the rare species of Pakistan. ${ }^{6}$ It is a perennial climber and hairless plant. Locally, it is named as Qanis, Varahikand, Singly-mingly, Kildri. Its rhizomes are arranged alternately and ligneous irregular. They are mostly in ginger type shape. Leaves are mostly simple and pointed, often heart shaped. In Pakistan, this species is mainly present in Kaghan Valley, Swat, Chitral, Shonala, Dir, Hazara, Galis, Kurram, Kashmir and in Murree regions. ${ }^{7}$ In Pakistan, its germination starts after the melting of snow in months of April-May, while its flowering period is June-July. It gives fruits in August-September. ${ }^{7}$

The chemical constituents found in $D$. deltoidea are 25-D-spirostan-3,5 diene, B-sitosterol, dioscorine, smilagenone, campastrol, diosgenin, stigmasterol and dioscin. Main reported constituents are ascorbic acid, aluminum, riboflavin, ash, chromium, calcium, niacin, cobalt, magnesium, beta-carotene, manganese, iron, phosphorus, selenium, protein, potassium, sodium, silicon, thiamine, zinc and tin. These chemical ingredients make this plant a manufacturing plant. ${ }^{7,8}$

Dioscorea deltoidea is used as wormicidal substance in children. Its tubers are used in uterine contractions.' Its rhizomes are used in treating biliary colic. ${ }^{10}$ The tuberous part of the plant is 
TABLE I: RESULTS OF ACUTE TOXICITY STUDY IN MICE FOR CRUDE SAPONIN RICH FRACTION OF DIOSCOREA DELTOIDEA

\begin{tabular}{|c|l|l|c|c|}
\hline Phases & Groups & \multicolumn{1}{c|}{ Dose (mg/kg) } & \% Lethality & \% survivors \\
\hline \multirow{4}{*}{ Phase I } & Group I & Normal saline (Nil)* & 0 & 100 \\
\cline { 2 - 5 } & Group II & Test substance 0.I & 0 & 100 \\
\cline { 2 - 5 } & Group III & Test substance I & 0 & 100 \\
\cline { 2 - 5 } & Group IV & Test substance I0 & 0 & 100 \\
\cline { 2 - 5 } & Group V & Test substance I00 & 0 & 100 \\
\hline \multirow{3}{*}{ Phase II } & Group VI & Test substance 500 & 0 & 100 \\
\cline { 2 - 5 } & Group VII & Test substance I000 & 0 & 100 \\
\hline
\end{tabular}

TABLE II: RESULTS OF CRUDE SAPONINS OF DIOSCOREA DELTOIDEA ON VARIOUS ORGANS DURING ACUTE TOXICITY STUDY

\begin{tabular}{|c|c|c|c|c|c|c|c|c|}
\hline \multirow{3}{*}{\multicolumn{2}{|c|}{ Symptoms }} & \multicolumn{7}{|c|}{ Intensity/Remarks } \\
\hline & & \multirow{2}{*}{\begin{tabular}{|c|} 
Normal \\
Saline
\end{tabular}} & \multicolumn{6}{|c|}{ Test Substance doses (mg/kg) } \\
\hline & & & 0.1 & I & 10 & 100 & 500 & 1000 \\
\hline \multicolumn{2}{|c|}{ Increase motor activity } & No & No & No & No & No & No & No \\
\hline \multicolumn{2}{|c|}{ Tremors } & No & No & No & No & No & No & No \\
\hline \multicolumn{2}{|c|}{ Clonic convulsion } & No & No & No & No & No & No & No \\
\hline \multicolumn{2}{|c|}{ Tonic extensor } & No & No & No & No & No & No & No \\
\hline \multicolumn{2}{|c|}{ Straub's reaction } & No & No & No & No & ++ & +++ & +++ \\
\hline \multicolumn{2}{|c|}{ Piloerection } & No & No & + & ++ & +++ & +++ & +++ \\
\hline \multicolumn{2}{|l|}{ Catatonia } & No & No & No & No & No & No & No \\
\hline \multicolumn{2}{|c|}{ Opisthotonos } & No & No & No & No & No & No & No \\
\hline \multicolumn{2}{|c|}{ Hyperesthesia } & No & No & No & No & No & No & No \\
\hline \multicolumn{2}{|c|}{ Loss of righting reflex } & No & No & No & No & No & No & No \\
\hline \multicolumn{2}{|c|}{ Decreased motor activity } & No & No & No & No & No & No & No \\
\hline \multicolumn{2}{|c|}{ Ataxia } & No & No & No & No & No & No & No \\
\hline \multicolumn{2}{|l|}{ Sedation } & No & No & No & No & ++ & +++ & +++ \\
\hline \multicolumn{2}{|l|}{ Hypnosis } & No & No & No & No & No & No & No \\
\hline \multicolumn{2}{|l|}{ Analgesia } & No & No & No & + & ++ & +++ & +++ \\
\hline \multicolumn{2}{|l|}{ Anesthesia } & No & No & No & No & No & No & No \\
\hline \multicolumn{2}{|c|}{ Arching and rolling } & No & No & No & No & No & No & No \\
\hline \multicolumn{2}{|c|}{ Ptosis } & No & No & No & No & + & +++ & +++ \\
\hline \multicolumn{2}{|l|}{ Lacrimation } & No & No & No & No & No & No & No \\
\hline \multicolumn{2}{|c|}{ Exophthalmos } & No & No & No & No & No & No & No \\
\hline \multirow{2}{*}{ Salivation } & Watery & No & No & No & No & No & No & No \\
\hline & Viscid & No & No & No & No & No & No & No \\
\hline \multicolumn{2}{|l|}{ Diarrhea } & No & No & No & No & No & No & No \\
\hline \multicolumn{2}{|l|}{ Shivering } & No & No & No & + & ++ & +++ & +++ \\
\hline \multirow{3}{*}{ Respiration } & Depression & No & No & No & No & No & No & No \\
\hline & Stimulation & No & No & No & No & ++ & +++ & +++ \\
\hline & Failure & No & No & No & No & No & No & No \\
\hline & Blanching & No & No & No & No & No & No & No \\
\hline Skin color & Flushing & No & No & No & No & No & No & No \\
\hline & Cyanosis & No & No & No & No & No & No & No \\
\hline
\end{tabular}

taken orally to cure dysentery, hemorrhoids and abdominal pain. ${ }^{11,12}$ The solution of Dioscorea deltoidea from rhizomes are used to cure ailments of central nervous system (CNS), orthopedic disorders, dermatitis, metabolic disorders, possess hypo-cholesterolemic, fungicide, antimicrobial, hemolytic, antitumor and biological activities. ${ }^{7.13}$ Diosgenin is a precursor to synthesize progesterone which is used in oral contraceptive pills. ${ }^{14}$ The tubers of $D$. deltoidea contain phytoconstituents like alkaloids, steroids, fats and fixed oil, flavonoids, tannins, proteins, carbohydrates and saponins. . $^{815}$ Saponins have been reported to possess a wide range of biological activities like antiulcer, antiviral, chemo preventive, cytotoxic, diuretic, analgesic and antiallergic. ${ }^{16}$ In general, saponins show analgesic activity. It has been previously tested for analgesic activity using animal models. Saponins inhibit writhing in mice and have showed analgesic activity. ${ }^{17,18}$ More, it has been reported that Dioscorea deltoidea has antiinflammatory and antimicrobial activity. ${ }^{19}$ Based on the phytochemicals and antinflammotory model in animals, we carried out current study to screen the saponins rich fraction of Dioscorea deltoidea for possible antinociceptive activity.

\section{METHODS}

The study was performed in Department of Pharmacology, Institute of Basic Medical Sciences, Khyber Medical University, Peshawar, Khyber Pakhtunkhwa, Pakistan. Ethical Board of the Khyber Medical University, Peshawar accorded approval of the Study protocols via approval No. DIR/KMU-EB/AT/000365.

Drugs and chemicals: Analytical grade chemicals were used. solvents and drugs used in experimental work such as methanol $80 \%$, n-butanol, chloroform, n-hexane, ethyl acetate, distilled water, tramadol, $0.7 \%$ acetic acid, diclofenac sodium and $0.9 \%$ normal saline.

Animals: Swiss albino mice of either sex having weight in range of $25-40 \mathrm{~g}$ were used in experiments. These mice were purchased from the animal house of Department of Pharmacy, University of Peshawar, KP, Pakistan. The mice were aclitimized on standard laboratory conditions $\left(25 \pm 2^{\circ} \mathrm{C} ; 12\right.$ hours light - 12 hours dark cycles). The animals were fed with standard food and water. ${ }^{20}$ 
After completion of the experimental protocols, the animals were disposed off as per procedure adopted by Safety and Bioethics Committee of the Institute of Basic Medical Sciences, Khyber Medical University.

Collection and identification of plant materials: The fresh rhizomes of Dioscorea deltoidea were collected from Sheringal valley, Dir (Upper), Khyber Pakhtunkhwa, Pakistan. The plant was collected in the month of July, which is its peak collection time. The plant was identified by Professor Dr. Jehandar Shah ex-vice chancellor and plant taxonomist, University of Malakand, Pakistan. A voucher specimen Dd-20I4 has been submitted to Department of Pharmacology, Khyber Medical University, Peshawar.

Isolation and extraction of plant materials: The fresh rhizomes of Dioscorea deltoidea were collected, washed and then dried in the shade for three weeks. The rhizomes were cut down into small pieces and then converted into fine powder with help of a mechanical grinder. The powdered material $(2.0 \mathrm{~kg})$ was soaked for one week in commercial grade methanol ( $80 \%)$ on room temperature with continuous shaking. The menstruum was then filtered through muslin cloth. This whole process was repeated three times. The different filtrates were then combined and filtered through Whatmann filter paper (No I). The filtrates were evaporated in a rotary evaporator on $40^{\circ} \mathrm{C}$ till a semisolid brown coloured methanolic extract (85.0 g) was obtained. ${ }^{21}$

Fractionation and phytochemical screenings: The crude methanolic extract $(85.0 \mathrm{~g})$ was suspended in distilled water. It was then successively fractionated with $n$-hexane, chloroform, ethyl-acetate and nbutanol. Each fraction was evaporated to dryness at $40^{\circ} \mathrm{C}$ using a rotary evaporator till it respectively yielded, n-hexane $(0.607 \mathrm{~g})$, chloroform $(6.42$ $\mathrm{g})$, ethyl-acetate (5.39 g),n-butanol (2.8 g) and residual aqueous fraction ( 12.15 g). The fractions were tested for the presence of saponins using frothing test and emulsification test. ${ }^{22}$ Frothing test was performed by adding different filtrates in $10 \mathrm{ml}$ of distilled water one by one. The mixture is shaken vigorously for 7-10 minutes. The formation of froth on the upper surface of mixture confirms the presence of saponins. Emulsification test was performed by the addition of 2-3 drops of olive oil in solution having froth formation. The solution was forcefully shaken for 2 minutes. The formation of uniform emulsion confirmed the existence of saponins. ${ }^{22}$ Each fraction was stored in airtight bottle at room temperature. The saponin- rich fraction was diluted in water for injection for in-vivo studies. ${ }^{23}$

Acute toxicity assay: It was performed on Swiss albino mice. Mice of either sex, having weight $25-40 \mathrm{~g}$, were used in the experiments. It was performed in two phases. Exponential doses of saponins rich fraction ( $\mathrm{n}$ butanol) in test doses of $0.1,1,10,100$ $\mathrm{mg} / \mathrm{kg}$ were administered $\mathrm{p} .0$ in phase I. While in phase II, 500 and $1000 \mathrm{mg} / \mathrm{kg}$ were administered orally. ${ }^{24}$ Death toll was recorded in 24 hours. Morbidity

\section{TABLE III: EFFECT OF CRUDE SAPONIN EXTRACT OF DIOSCOREA} DELTOIDEA ON ACETIC ACID INDUCED WRITHING MICE

\begin{tabular}{|l|l|l|c|c|}
\hline Treatment & Groups & Dose (mg/kg) & $\begin{array}{c}\text { Number of } \\
\text { writhing }\end{array}$ & $\begin{array}{c}\% \text { inhibition } \\
\text { of writhing }\end{array}$ \\
\hline Negative control group & Group I & Normal saline (Nil) & $49 \pm 5.65$ & --- \\
\hline \multirow{4}{*}{ Test groups } & Group II & Test substance I & $37.5 \pm 2.12 *$ & 23.5 \\
\cline { 2 - 5 } & Group III & Test substance 5 & $21.5 \pm 6.36 *$ & 56.12 \\
\cline { 2 - 5 } & Group IV & Test substance I0 & $12 \pm 5.65 *$ & $75.5 \mathrm{I}$ \\
\cline { 2 - 6 } & Group V & Test substance 50 & $7 \pm 1.4 I^{*}$ & $85.7 \mathrm{I}$ \\
\hline Standard group & Group VI & Diclofenac sodium 50 & $12.5 \pm 3.53 *$ & 74.4 \\
\hline
\end{tabular}

TABLE IV: EFFECT OF CRUDE SAPONIN EXTRACT OF DIOSCOREA DELTOIDEA ON LATENCY TIME IN HOT PLATE TEST

\begin{tabular}{|c|c|c|c|c|c|c|c|}
\hline \multirow{2}{*}{ Treatment } & \multirow{2}{*}{ Groups } & \multirow{2}{*}{$\begin{array}{l}\text { Dose } \\
(\mathrm{mg} / \mathrm{kg})\end{array}$} & \multicolumn{5}{|c|}{ Mean latency time before and after drug administration } \\
\hline & & & $0 \min (\mathrm{sec})$ & $30 \mathrm{~min}(\mathrm{sec})$ & $60 \mathrm{~min}(\mathrm{sec})$ & $90 \mathrm{~min}(\mathrm{sec})$ & $120 \mathrm{~min}(\mathrm{sec})$ \\
\hline $\begin{array}{l}\text { Negative } \\
\text { Control } \\
\text { Group }\end{array}$ & Group I & $\begin{array}{c}\text { Normal } \\
\text { saline(Nil) }\end{array}$ & $12.75 \pm 5.72$ & $11.85 \pm 2.19$ & $12.85 \pm 6.29$ & $11.15 \pm 1.66$ & $12.8 \pm 0.84$ \\
\hline \multirow{3}{*}{$\begin{array}{l}\text { Test } \\
\text { groups }\end{array}$} & Group II & $\begin{array}{c}\text { Test sub- } \\
\text { stance } 10\end{array}$ & $12.2 \pm 5.37$ & $27.8 \pm 0.28 *$ & $23.1 \pm 3.39 *$ & $20.75 \pm 0.6 * 3$ & $17.65 \pm 2.33 *$ \\
\hline & Group III & \begin{tabular}{|c|} 
Test sub- \\
stance 50
\end{tabular} & II $.67 \pm 5.4$ & $29.85 \pm 1.48 *$ & $29.1 \pm 0.98 *$ & $26.55 \pm 0.35 *$ & $23.6 \pm\left. 1.4\right|^{*}$ \\
\hline & Group IV & $\begin{array}{c}\text { Test sub- } \\
\text { stance I00 }\end{array}$ & $13.5 \pm 2.00$ & $36.1 \pm 1.55 *$ & $35.1 \pm 0.84 *$ & $36.5 \pm 4.66 *$ & $26.7 \pm 4.52 *$ \\
\hline $\begin{array}{l}\text { Standard } \\
\text { group }\end{array}$ & Group V & $\begin{array}{c}\text { Tramadol } \\
30\end{array}$ & $13.4 \pm 1.23$ & $27.3 \pm 3.1 I^{*}$ & $27.05 \pm 2.47$ * & $26.1 \pm 1.69^{*}$ & $22.5 \pm 6.92 *$ \\
\hline
\end{tabular}


minutes of acetic acid administration, writhings were counted for 10 minutes. Each mouse was observed separately for accurate measuring. The numbers of writhing in the test group was compared with standard control group. $^{25}$ The percent inhibition of writhing was calculated to determine analgesic activity using following formula:

$\%$ Inhibition of writhing =

Writhing in Control Group - writing in test group x 100 Writing in Control Group

Hot plate method: Eddy's hot plate method was used to determine analgesia. Swiss albino mice of either sex were used having weight $25-40 \mathrm{~g}$. Animals were divided into five groups, four animals in each group. Hot plate was maintained on $55^{\circ} \mathrm{C}$ before the start of the experiments. Hot plate generates electrical heat that causes pain. The indication of animal's response to pain induced by heat was licking of the hind paw and coming out of the beaker. Group I received normal saline, which served as negative control. Group II received tramadol $30 \mathrm{mg} / \mathrm{kg}$, which served as positive control. Saponin rich fraction (n-butanol) in the test doses of $10,50,100 \mathrm{mg} / \mathrm{kg}$ were administered to group III, IV, V respectively through intraperitoneal route. Readings were taken on $0,30,60$, 90 and 120-min intervals using a hot plate. $^{26,}{ }^{27}$ Percent latency time was calculated using the following formula:

$\%$ Analgesia $=\frac{(\text { Test latency }- \text { Control latency })}{(\text { Cut off time }- \text { Control latency })} \times 100$

Statistical analysis: For $\mathrm{LD}_{50}$, percent mortality was plotted versus test dose administered. Number of writhing were noted and \% inhibition of writhing was determined versus respective standard drug. Latency time was calculated and plotted amongst different groups using tramadol as standard drug. Data was plotted and analyzed using Graph Pad Prism 6. ANOVA was used to determine the significance of test samples versus positive control at $95 \% \mathrm{Cl}$ with $\mathrm{p}<0.05$.

\section{RESULTS}

Phytochemical Screening:
Phytochemical test revealed that saponnins were rich in $n$-butanol fraction and residual aquous fractions as it produced significant frothing and uniform emulsion upon addition of olive oil.

Effects of acute toxicity activity: The crude saponin rich n-butanol fractionwas safe up to $1000 \mathrm{mg} / \mathrm{kg}$, and there were no mortalities found (Table I). There were no gross behavioral changes for 24 hours study while sedation, ptosis, increased respiration, piloerection, straub's reaction and shivering were observed on higher doses as shown in Table II. According to the results, the fraction was safe up to $1000 \mathrm{mg} / \mathrm{kg}$ and can be used for further studies. However, sedation and analgesia in this phase further guided us that the test samples have possible analgesic activity through involvement of CNS.

Analgesic activity: Results for possible analgesic activity are as under:

Acetic acid induced writhing method: According to the results, test samples on 10 and $50 \mathrm{mg} / \mathrm{kg}$ showed maximum inhibition of writhings as compared to negative control group. Test substance in $10 \mathrm{mg} / \mathrm{kg}$ and $50 \mathrm{mg} / \mathrm{kg}$ showed $75.51 \%$ and $85.71 \%$ inhibition of writhing, while diclofenac sodium showed $74.4 \%$ inhibition of writhing. This implies that test substance is more potent as compared to our standard drug as shown in Table III.

Hot plate method: The results of the crude saponin rich extract showed more \% inhibition of latency time as compared to standard drug and \% inhibition of latency time of extract increased from $87.87 \%$ to $133.6 \%$ in $10 \mathrm{mg} / \mathrm{kg}$ to $100 \mathrm{mg} / \mathrm{kg}$ dose respectively while tramadol showed the latency time of $85.12 \%$ within 30 minutes of administration (Table IV).

\section{DISCUSSION}

The main focus of our study is to confirm the possible antinociceptive activity of crude saponins rich fraction of Dioscorea deltoidea. This was accomplished by two different methods. The acetic acid-induced writhing method is due to the involvement of peripheral nervous system while thermal nociception models that is hot plate method is due to the involvement of central nervous system mechanism for possible analgesia. ${ }^{28}$ Arachidonic acid has an important role in pain and inflammation. It causes the release of inflammatory mediators like prostaglandins and cytokines through cyclo-oxygenase and lipo-oxygenasepathways as prostaglandins mediate pain. ${ }^{29}$ Acetic acid causes pain sensation by the release of inflammatory mediators. Phospholipids are present in tissues that cause the release of arachidonic acid which in turn causes the synthesis of prostaglandins through cyclooxygenase pathway. These prostaglandins stimulate the nociceptive neurons with initiation of pain sensation. The main prostaglandins that are involved in pain are PGE2 and PGF2 $\alpha$ that are present in peritoneal fluids. The increase in prostaglandins level causes pain by increasing the capillary permeability. The writhing / abdominal constriction method is widely used to assess possible analgesic activity of a test sample that acts through the peripheral pathway. Literature suggests that any substance which inhibits the writhing/abdominal constrictions will have possible analgesic action by inhibiting the release of prostaglandins. ${ }^{30,31}$

NSAIDs inhibit the cyclo-oxygenase pathway and subsequently inhibit the release of prostaglandins. Hence, the analgesic activity of NSAIDs confirm the association of peripheral mechanism in pain reduction. That is why NSAIDs are used as positive control in writhing model. Thus, saponins rich samples follow the peripheral pathway for inhibition of the release of prostaglandins. Maximum analgesic action was observed with $10 \mathrm{mg} / \mathrm{kg}$ and $50 \mathrm{mg} / \mathrm{kg}$ that respectively decreased the writhings by $75.51 \%$ and $85.71 \%$. While diclofenac sodium decreased writhings by $74.4 \%$.

Thermal nociception model such as hot plate method also predicts the possible analgesic activity through involvement of central nervous system. Thermal nociceptor neurons are excited by thermal noxious stimulus in the skin or 
in visceral organs. This is best explained as thermal stimulus induces pain due to which animal withdraws its hind paw. ${ }^{27}$ Thus, our results suggest that test sample in dose of $50 \mathrm{mg} / \mathrm{kg}$ and 100 $\mathrm{mg} / \mathrm{kg}$ showed more latency time as compared to effects produced by tramadol within 30 minutes of its administration. The difference in latency time could be explained by the difference in the metabolic rate of each drug, or maybe there is the difference in potency of each drug. Moreover, crude saponins rich fraction of $D$. deltoidea showed maximum analgesic effect within 30 minutes of administration, which sustained for 120 minutes. Literature suggests that the Dioscorea species show analgesic activity.

Thus, it is deduced that analgesic effects of crude saponin rich fraction of $D$. deltoidea involveboth peripheral and central mechanisms.

\section{CONCLUSION}

Our current results confirm that nbutanol fraction of Dioscorea deltoidea has analgesic activity through involvement of both peripheral as well as central nervous system nociceptive inhibitory mechanisms. Subsequent extraction and pharmacological screening of the phytochemicals of saponins may help in development of new analgesic drugs from the saponin rich fraction of the Dioscorea deltoidea.

\section{ACKNOWLEDGEMENT}

The authors want to thank Professor Dr. Jahandar Shah for identification of the plant species.

\section{REFERENCES}

I. Serpell M. Anatomy, physiology and pharmacology of pain. Surgery 2006;24(I0):350-3. DOI: 10.1053 /j.mpsur.2006.08.002.

2. Shoaib M, Shah SWA, Ali N, Shah I, Ullah S, Ghias $M$, et al. Scientific investigation of crude alkaloids from medicinal plants for the management of pain. BMC Complement Altern Med 2016;16(1):178. DOI: 10.1186/ s|2906-0|6-||157-2

3. Malairajan P, Gopalakrishnan G,
Narasimhan S, Veni KJK. Analgesic activity of some Indian medicinal plants. J Ethnopharmacol 2006;106(3):425-8. DOI: 10.1016/ j.jep.2006.03.015

4. Khan MA, Rahman AA, Nahar L, Islam $M B$, Alam AK. In vivo analgesic and CNS depressant activities of antioxidative stem bark fraction of Morus alba L. J Pharm Sci 2014; I3(2):225-7. DOI: 10.3329/dujps. v13i2.21905.

5. Dutta B. Food and medicinal values of certain species of Dioscorea with special reference to Assam. J Pharmacogn Phytochem 2015;3(4): I5-8

6. Dangwal L, Chauhan AS. Dioscorea deltoidea wall. Ex Griseb. A Highly Threatened Himalayan Medicinal Plant: An Overview. Int J Pharm Bio Sci 20I5;6(I): 452-460.

7. Tahir N, Bibi Y, Iqbal M, Hussain M, Laraib S, Safdar I, et al. Overview of Dioscorea deltoidea Wall. Ex Griseb: An Endangered Medicinal Plant from Himalaya Region. J Biodivers Environ Sci 2016;9(6):13-24.

8. Chandra S, Saklani S, Mishra AP. In vitro Antimicrobial Activity of Garhwal Himalaya Medicinal Plant Dioscorea deltoidea Tuber. Int J Herb Med 20 I 3; I (4):67-70.

9. Hamayun M. Traditional uses of some medicinal plants of Swat Valley, Pakistan. 2007. Indian J Traditional Knowledge 2007;6:636-4I.

10. Muslim M. Sikander S. Ethnobotany of medicinal plants of Leepa Valley (Azad Kashmir). Pak J Forestry 2010;60(2):21-30.

11. Mustafa A, Ahmad A, Tantray AH, Parry PA. Ethnopharmacological Potential and Medicinal Uses of Miracle Herb Dioscorea spp. J Ayu Her Med 20 I 8;4(2):79-85.

12. Priti K, Joshi GC, Tewari LM. Indigenous uses of threatened ethnomedicinal plants used to cure different diseases by ethnic people of Almora district of western Himalaya. Int J Ayurvedic Herb Med 20 I 2;2(04):66I78.

13. Razaq A, Rashid A, Ali H, Ahmad H, Islam M. Ethnomedicinal potential of plants of Changa Valley District, Shangla, Pakistan. Pakistan J Bot
2010;42(5):3463-75.

14. Asha K, Nair GM. Screening of Dioscorea species for diosgenin from southern Western Ghats of India. Indian J Plant Genet Resour 2005; | 8(2):227-30.

I5. Sharma V, Ramawat KG. Tuberous Medicinal Plants of India. In: Ramawat KG, Merillon J Bulbous Plants. I $^{\text {st }}$ ed. India: CRC Press; 2013.p 3।I-37.

16. Güçlü-Üstündağ Ö, Mazza G. Saponins: properties, applications and processing. Crit Rev Food Sci Nutr 2007;47(3):231-58. DOI: 10.1080/10408390600698/97

17. Chindo B, Anuka J, Isaac E, Ahmadu A, Tarfa F, Gamaniel K. Saponins are involved in the analgesic and antiinflammatory properties of Ficus platyphylla stem bark. Int J Biol Chem Sci 20I0;4(2):415-23.

18. Borgi W, Recio M-C, Ríos J, Chouchane N. Anti-inflammatory and analgesic activities of flavonoid and saponin fractions from Zizyphus lotus (L.) Lam. S Afr J Bot 2008;74(2):320-4. DOI: 10.1016/j.sajb.2008.01.009.

19. Gyawali R. Antiinflammatory and Antimicrobial Property of Dioscorea deltoidea L from Nepal. Int J Pharm Biol Arch 20I5;5(4).

20. Sharp P, Villano JS. The laboratory rat. $2^{\text {nd }}$ ed: CRC press; 2012.

21. Ali N, Alam H, Khan A, Ahmed G, Shah WA, Nabi M, et al. Antispasmodic and antidiarrhoeal activity of the fruit of Rosa moschata (J). BMC Complement Altern Med 20I4;I4(I):485. DOI: 10.1 186/ 1472-6882-14-485

22. Mir MA, Parihar K, Tabasum U, Kumari E. Estimation of alkaloid, saponin and flavonoid, content in various extracts of Crocus sativa. J Med Plants Stud 20 I 6;4(5): I 7 I -4.

23. Ali N, Shah I, Shah SWA, Ahmed G, Shoaib M, Junaid M, et al. Antioxidant and relaxant activity of fractions of crude methanol extract and essential oil of Artemisia macrocephala jacquem. BMC Complement Altern Med 2013;13(I):96. DOI: 10.1 186/1472-6882-13-96.

24. Ali N, Ahmed G, Shah SWA, Shah I, Ghias M, Khan I. Acute toxicity, brine shrimp cytotoxicity and relaxant activity of fruits of callistemon citrinus curtis. BMC Complement Altern Med 
20II;II(I):99. DOI: I0.II86/I4726882-11-99.

25. Ullah HA, Zaman S, Juhara F, Akter L, Tareq SM, Masum EH, et al. Evaluation of antinociceptive, in-vivo \& in-vitro anti-inflammatory activity of ethanolic extract of Curcuma zedoaria rhizome. BMC Complement Altern Med 20I4; I4(I):346. DOI: 10.1 I86/ I4726882-I4-346.

26. Afsar T, Khan MR, Razak S, Ullah S, Mirza B. Antipyretic, antiinflammatory and analgesic activity of Acacia hydaspica R. Parker and its phytochemical analysis. BMC Complement Altern Med 2015;15(I):136. DOI: 10.1186 /s|2906-015-0658-8.

27. Muhammad N, Saeed M, Khan $H$. Antipyretic, analgesic and antiinflammatory activity of Viola betonicifolia whole plant. BMC Complement Altern Med 20I2;12(I):59. DOI: 10.1I86/14726882-12-59.
28. Shoaib M, Shah I, Ali N, Shah WA. A mechanistic approach to antinociceptive potential of Artemisia macrocephala J acquem. BMC Complement Altern Med 2016;16(I):I4I. DOI: 10.1I86 /s12906-016-II||4-0.

29. Ali N, Sultana U, Shah SWA, Nabi M, Shah I, Ahmed G. Acute toxicity and analgesic activity of crude flavonoids of achillea wilhelmsii and teucrium stocksianum. Khyber Med Univ J 20I6;8(I):7-II. DOI: I0.35845/ kmuj.2016.15844.

30. Zulfiker A, Rahman MM, Hossain MK, Hamid K, Mazumder M, Rana MS. In vivo analgesic activity of ethanolic extracts of two medicinal plantsScoparia dulcis L. and Ficus racemosa Linn. Biol Med 20 I 0;2 (2):42-8.

31. Gawade S. Acetic acid induced painful endogenous infliction in writhing test on mice. J Pharmacol Pharmacother 20I2;3(4):348. DOI: 10.4103/0976$500 \times .103699$.
32. Islam T, Begum A, Shahed-AlMahmud. Antinociceptive Activity of Methanol Extract of Dioscorea Pentaphylla Linn. Leaves in Mice. Adv in Pharmacol Pharm 20 8; 6(3):65-7I. DOI: I0.13 I89/app.20I8.06030 |

33. Lima CM, Lima AK, Melo MGD, Serafini MR, Oliveira DL, de Almeida $E B$, et al. Bioassay-guided evaluation of Dioscorea villosa-an acute and subchronic toxicity, antinociceptive and anti-inflammatory approach. BMC Complement Altern Med 2013; I3(I): I95. DOI: 10.1 I86/ I4726882-13-195.

34. Nguelefack TB, Dutra RC, Paszcuk AF, Andrade EL, Tapondjou LA, Calixto JB. Antinociceptive activities of the methanol extract of the bulbs of Dioscorea bulbifera L. Var sativa in mice is dependent of NO-cgmp-ATPsensitive-K+ channel activation. J Ethnopharmacol 20I0; I28(3):56774. DOI: 10.1016/j.jep.2010.01.06।

\section{AUTHORS' CONTRIBUTIONS}

Following authors have made substantial contributions to the manuscript as under:

NA: Conception and study design, analysis and interpretation of data, drafting the manuscript, critical review, final approval of the version to be published.

$\mathbf{N}, \mathbf{M N}$ : Acquisition of data, drafting the manuscript, final approval of the version to be published.

ZS, US \& BS: Acquisition, analysis and interpretation of data, drafting the manuscript, final approval of the version to be published.

SU: Analysis and interpretation of data, drafting the manuscript, final approval of the version to be published.

Authors agree to be accountable for all aspects of the work in ensuring that questions related to the accuracy or integrity of any part of the work are appropriately investigated and resolved

CONFLICT OF INTEREST
Authors declared no conflict of interest
GRANT SUPPORT AND FINANCIAL DISCLOSURE
NIL

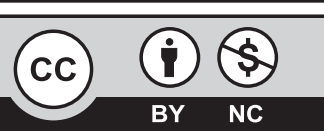

This is an Open Access article distributed under the terms of the Creative Commons Attribution-Non Commercial 2.0 Generic License.

KMUJ web address: www.kmuj.kmu.edu.pk

Email address: kmuj@kmu.edu.pk 